\title{
Niche differentiation mechanisms among canopy frugivores and zoochoric trees in the northeastern extreme of the Amazon
}

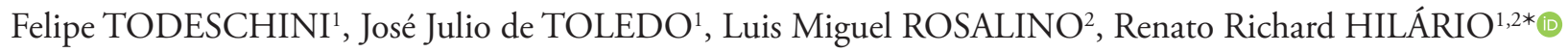 \\ Universidade Federal do Amapá (UNIFAP), Programa de Pós-Graduação em Biodiversidade Tropical, Rod. JK, km 2, Jardim Marco Zero, 68903-419, Macapá, Amapá, Brazil \\ 2 Universidade de Lisboa, Faculdade de Ciências, cE3c - Centre for Ecology, Evolution and Environmental Changes, Campo Grande, 1749-016, Lisboa, Portugal \\ * Corresponding author: renatohilario@gmail.com; (10) https://orcid.org/0000-0002-0346-0921
}

\begin{abstract}
Frugivores and zoocoric trees represent an important proportion of tropical rainforest biodiversity. As niche differences favor species coexistence, we aimed to evaluate morphological and temporal niche segregation mechanisms among zoochoric trees and canopy frugivores in a tropical rainforest in the northeastern extreme of the Brazilian Amazon. We tested the effects of fruit morphology, tree size, frugivore body size and time of day on fruit consumption. We recorded the frugivore species that fed on 72 trees (44 species, 22 genera) and whether these frugivores swallowed the seeds. We monitored trees only once from 07:00 to 17:00 h between January and September 2017. We observed fruit consumption in 20 of the 72 trees. Seventy-three frugivore individuals from 22 species visited the trees. Heavier fruits were consumed by larger frugivores, while seed size was inversely correlated with frugivore size. Narrower fruits and fruits with smaller seeds had greater probability of having their seeds ingested, and larger frugivores were more prone to ingest seeds. Trees bearing fruits with smaller seeds were visited by a greater number of frugivores. Taxonomic groups differed in the time of arrival at fruiting trees. None of the evaluated variables (fruit weight and size, and seed size) affected the richness of frugivores that visited the trees. We concluded that, in the studied forest, fruit morphology (weight, size and seed size) is a niche segregation mechanism among zoochoric trees, while body size and time of day are niche segregation mechanisms among frugivores.
\end{abstract}

KEYWORDS: Amapá National Forest, frugivory, phenology, seed dispersal, tropical rainforest

\section{Mecanismos de diferenciação de nicho entre frugívoros de copa e árvores zoocóricas no extremo nordeste da Amazônia brasileira}

\section{RESUMO}

Frugívoros e árvores zoocóricas representam uma proporção relevante da biodiversidade de florestas tropicais. Uma vez que a diferenciação de nicho favorece a coexistência das espécies, nós objetivamos investigar mecanismos morfológicos e temporais de segregação de nicho entre árvores zoocóricas e frugívoros de copa em uma floresta tropical no extremo nordeste da Amazônia brasileira. Testamos os efeitos da morfologia dos frutos, tamanho das árvores, tamanho corporal dos frugívoros e hora do dia sobre o consumo de frutos. Registramos as espécies de frugívoros que se alimentaram em 72 árvores (pertencentes a 44 espécies e 22 gêneros) e se esses frugívoros ingeriam sementes. Monitoramos cada árvore apenas uma vez, de 07:00 a 17:00 h, entre janeiro e setembro de 2017 e observamos o consumo de frutos em 20 das 72 árvores. Setenta e três indivíduos de frugívoros, pertencentes a 22 espécies, visitaram as árvores. Frutos mais pesados foram consumidos por frugívoros maiores, enquanto o tamanho das sementes foi inversamente correlacionado ao tamanho dos frugívoros. Frutos menores e com sementes menores tiveram uma maior probabilidade de ter suas sementes ingeridas, e frugívoros maiores apresentaram maior tendência a ingerir as sementes. Árvores com frutos com sementes menores foram visitadas por um maior número de indivíduos de frugívoros. Os grupos taxonômicos de frugívoros diferiram no tempo de chegada às árvores. Nenhuma das variáveis analisadas (peso e tamanho dos frutos e tamanho das sementes) afetou a riqueza de frugívoros que visitaram as árvores. Concluímos que, na floresta estudada, a morfologia dos frutos (tamanho, peso e tamanho das sementes) é um mecanismo de segregação entre árvores zoocóricas, enquanto tamanho corporal e horário do dia são mecanismos de segregação entre frugívoros.

PALAVRAS-CHAVE: Floresta Nacional do Amapá, frugivoria, fenologia, dispersão de sementes, floresta tropical úmida 


\section{INTRODUCTION}

Frugivory is an important ecological interaction in which animals gain food while plants may have their seeds dispersed. This relationship is critical in tropical forests, where between $62.1 \%$ and $93.5 \%$ of woody species are dependent on animals for seed dispersal (Jordano 2000). Many frugivores ingest seeds together with the fruit pulp, and then defecate the intact seeds (Jordano 2000; Fricke et al. 2013). Passage through the gut of a frugivore often increases seed germinability (Traveset et al. 2007; Rosalino et al. 2010; Jordaan et al. 2011). Furthermore, seed dispersers take the seeds away from the parent tree, reducing competition among seedlings and attack by pathogens and predators (Warren and Giladi 2014).

Birds and mammals are the main tropical frugivores and seed dispersers (Herrera 2002; Chen and Moles 2015) and may feed on up to $75 \%$ of the fruit species throughout the tropics (Uriarte et al. 2011; Bello et al. 2015). Between 25\% and $35 \%$ of Neotropical birds are frugivores (Pizo and Galetti 2000). Among mammals, primates are the main arboreal frugivores (Fleming and Kress 2011), and seed dispersal by primates is important since they can swallow larger seeds than most birds and bats (Gardner et al. 2019).

Niche differentiation favors species coexistence (Chesson 2000; Chase and Leibold 2003), and strategies of both frugivores and zoochoric trees to increase niche segregation with their competitors may affect how they interact with each other (i.e. different plant species should attract different frugivores, and different frugivores may feed on different plant species). However, there is also convergence in fruit and frugivore traits in response to evolutionary selective pressures (Lomáscolo et al. 2010; Dehling et al. 2016), creating redundancy in the seed dispersal interaction (Zamora 2000). The evolutionary patterns shaped by frugivory and seed dispersal may be complex, since successful germination and plant establishment sometimes depend on secondary dispersal by ants, beetles or rodents (Vander Wall and Longland 2004; Camargo et al. 2019), which may also shape fruit traits (Vander Wall and Longland 2004).

Plants may segregate spatially, so that each species performs with optimal fitness in a different environment (Svenning 2001; Kraft et al. 2008), or in a different vertical stratum (Silvertown 2004). Niche segregation can also be temporal, when different species produce flowers and fruits at different times of the year (Günter et al. 2008; MunguíaRosas et al. 2011), or morphological, when plants produce morphologically different fruits and flowers to attract different frugivores and pollinators (Flörchinger et al. 2010; Dehling et al. 2016). These niche differentiation mechanisms can directly affect frugivory, since plant phenology, spatial distribution, nutritional content, and fruit morphology determine frugivore feeding choices (Leiner et al. 2009; Flörchinger et al. 2010; Dehling et al. 2016).
Frugivorous animals also display niche differentiation, which may be spatial, when species occupy different vegetation types or different vertical strata (Poulsen et al. 2002; Bersacola et al. 2015), or morphological/behavioral, when species feed on fruits with distinct colors, shapes, and sizes (Flörchinger et al. 2010; Dehling et al. 2016). For example, gape size limits the size of fruit that a frugivore can ingest (Moran and Catterall 2010; Burns 2013; Galetti et al. 2013). There may also be temporal niche segregation among frugivores, as when nocturnal and diurnal frugivores feed on the same fruits in different periods of the day (Mello et al. 2011).

Understanding niche segregation mechanisms may contribute to explain the high biodiversity in tropical forests, which are the most biodiverse environments globally (Lewis et al. 2015). Nevertheless, most studies investigating frugivoryrelated niche segregation have focused only on a few pairs of species (Russo 2003; McConkey et al. 2014; Moreira et al. 2017; Pegman et al. 2017), which is insufficient to understand niche segregation patterns at the community level. In addition, temporal niche segregation between frugivores is poorly understood. Therefore, the aim of this study was to fill these information gaps by evaluating how fruit, seed, and tree characteristics affect fruit consumption by canopy frugivores, and how the attributes of these frugivores are related to fruit consumption in a Neotropical rainforest. We expected that frugivore body size is related to the traits of the fruits they consume, and to whether they swallow the seeds or not. In turn, we expected that fruit traits and tree size are related to the probability of the fruit and its seeds being ingested, and affect the richness and abundance of frugivores that feed on them. Finally, we predicted that the prevalence of ripe fruit in the forest affects the visitation of the trees by frugivores, and that different taxonomic groups of frugivores will differ in the time of arrival at the fruiting trees. Our hypotheses and their underlying reasoning are explained in more detail in Table 1.

\section{MATERIAL AND METHODS}

\section{Study site}

The study was performed during a 10-month period (November 2016 to September 2017) in the Amapá National Forest (ANF), located in the northeastern extreme of the Brazilian Amazon, in the Guiana Shield region. ANF is a protected area consisting of 459,867 ha of mostly pristine evergreen forests (ICMBio 2014) surrounded by two additional protected areas, the Amapá State Forest and Mountains of Tumucumaque National Park (ICMBio 2014). Fieldwork was authorized by Instituto Chico Mendes de Conservação da Biodiversidade (SISBIO license \# 49776-2). Information about arboreal frugivores in ANF is still scarce, but previous inventories reported 110 and 14 of, at least partially frugivorous species of birds and arboreal/ 
Table 1. Hypotheses established for the evaluation of the relation among zoochoric trees and canopy frugivores in Amapá National Forest (Amapá, Brazil) and their underlying reasoning.

\begin{tabular}{|c|c|}
\hline Hypotheses & Reasoning \\
\hline $\begin{array}{l}\text { H1 - Larger frugivores will consume heavier and larger } \\
\text { fruits, and fruits with larger seeds. }\end{array}$ & $\begin{array}{l}\text { Larger frugivores are stronger (Sekar and Sucumar 2013) and have larger gape sizes (Moran and } \\
\text { Catterall 2010; Burns 2013; Galetti et al. 2013) allowing them to cope with heavier and larger fruits, } \\
\text { and with fruits with larger seeds. }\end{array}$ \\
\hline $\begin{array}{l}\text { H2 - Larger frugivores will prefer to feed on larger trees } \\
\text { (larger DBH). }\end{array}$ & $\begin{array}{l}\text { Larger trees bear higher fruit abundance (Chapman et al. 1992), supplying more efficiently the } \\
\text { higher energetic demand of larger frugivores (Hawes and Peres 2014). }\end{array}$ \\
\hline $\begin{array}{l}\text { H3 - Larger frugivores will swallow the seeds more } \\
\text { frequently than smaller ones. }\end{array}$ & $\begin{array}{l}\text { Gape size, which is related to frugivore size, limits the size of seeds that can be swollen by frugivores } \\
\text { (Moran and Catterall 2010; Galetti et al. 2013). }\end{array}$ \\
\hline $\begin{array}{l}\text { H4 - Smaller fruits will have their seeds swallowed more } \\
\text { frequently than larger fruits. }\end{array}$ & $\begin{array}{l}\text { Given the limiting effect of gape size in the ingestion of fruits (Moran and Catterall 2010; Burns } \\
\text { 2013), more frugivores should be able to swallow the smaller fruits as a whole (Jordano 2000; Muñoz } \\
\text { et al. 2016). }\end{array}$ \\
\hline $\begin{array}{l}\text { H5 - Fruits with smaller seeds will have their seeds } \\
\text { swallowed more frequently than fruits with larger seeds. }\end{array}$ & $\begin{array}{l}\text { Larger seeds occupy more space within the frugivore gut (Jordano 2000), limiting the ingestion of } \\
\text { fruit pulp. Thus, frugivores must avoid ingesting larger seeds. }\end{array}$ \\
\hline $\begin{array}{l}\text { H6 - The richness and abundance of frugivores that visit } \\
\text { a given fruit tree will be related to fruit traits, such as size, } \\
\text { weight, as well as seed size. }\end{array}$ & $\begin{array}{l}\text { Fruit size and weight, as well as seed size may constrain the consumption of such fruits by some } \\
\text { frugivore species (Moran and Catterall 2010; Galetti et al. 2013; Blendinger et al. 2016). }\end{array}$ \\
\hline $\begin{array}{l}\text { H7 - Larger trees will attract a large number of frugivore } \\
\text { individuals and species. }\end{array}$ & Larger trees may be more conspicuous and produce higher fruit abundance (Chapman et al. 1992). \\
\hline $\begin{array}{l}\text { H8 - Frugivore richness and abundance in the focal trees } \\
\text { will be higher in months with lower prevalence of ripe } \\
\text { fruits. }\end{array}$ & $\begin{array}{l}\text { Frugivores will concentrate their feeding in the few trees bearing fruits in months with low fruit } \\
\text { prevalence (Stevenson et al. 2000, Saracco et al. 2005). }\end{array}$ \\
\hline $\begin{array}{l}\mathrm{H} 9 \text { - Taxonomic groups will differ in the time of arrival in } \\
\text { the fruiting tree. }\end{array}$ & $\begin{array}{l}\text { Taxonomic groups differ regarding predation risk, and physiological constraints that may influence } \\
\text { the time of activity onset (Taufique et al. 2006; Saggese et al. 2011). }\end{array}$ \\
\hline
\end{tabular}

scansorial mammals, respectively (Sick 1997; Reis et al. 2006; Supplementary Material, Table S1).

The climate in ANF is classified as Af (tropical forest climate) according to Köppen's classification (ICMBio 2014). Maximum and minimum temperatures are approximately $32^{\circ} \mathrm{C}$ and $22^{\circ} \mathrm{C}$, respectively. Average annual rainfall is 2284 $\mathrm{mm}$, concentrated between December and July, with a dry season from August to mid-December, yet rainfall is typically above $60 \mathrm{~mm}$ even in the driest months (ICMBio 2014).

\section{Sampling design}

A $5 \times 5-\mathrm{km}$ grid of trails of the Research Program on Biodiversity (PPBio) (https://ppbio.inpa.gov.br/en/home) is located in the southern region of the ANF (Figure 1), and includes 30 standardized sampling plots $(40 \times 250 \mathrm{~m})$ (ICMBio 2014). Our study was performed in five of these plots (Figure 1). We identified the zoochoric trees $[>10 \mathrm{~cm}$ $\mathrm{DBH}$ (diameter at breast height)] in the plots and recorded their $\mathrm{DBH}$, since it is correlated with fruit production (Chapman et al. 1992). The trees were identified by an experienced parataxonomist following Byng et al. (2016). Although $59.5 \%$ of the trees in the plots were zoochoric, most of the zoochoric species had only one or two individuals in the study plots. Therefore, we initially selected 942 trees belonging to species that had three or more individual trees in the five plots, to allow for at least 30 hours of observation for each species. The 942 trees were monitored monthly from November 2016 to September 2017 to register whether they bore ripe fruits.

We used the focal-tree method (Galetti et al. 2013) to record vertebrate frugivore species feeding on each tree and whether the frugivore species typically swallowed or discarded the seeds of the focal tree. Each month, we selected four to 10 trees bearing ripe fruits over at least $30 \%$ of their canopies to monitor frugivore visits, totaling 72 trees, pertaining to 44 species and 22 genera. To keep independence among samples, each focal tree was monitored only once throughout the study, at a time when it was bearing fruit. By sampling each tree only once, we avoided the bias associated with pseudoreplication of repeated monitorings of the same tree. Ideally, we aimed to select focal individuals of the same species, to avoid increased variability associated with distinct species. However, due to the limited availability of conspecific fruit-bearing trees, in some cases we had to select focal individuals of different congeneric species. Although the variation in fruit traits (e.g. size) across species is often higher than variation within species (Mubo et al. 2004), this was not the case for most of the genera in this study, with the exception of Protium (data available at: https://ppbiodata.inpa.gov.br/metacatui/\#view/ PPBioAmOc.229.4). Although acknowledging this limitation, we used congeneric trees to allow the inclusion of this genus in our study (otherwise it would have to be excluded), because 


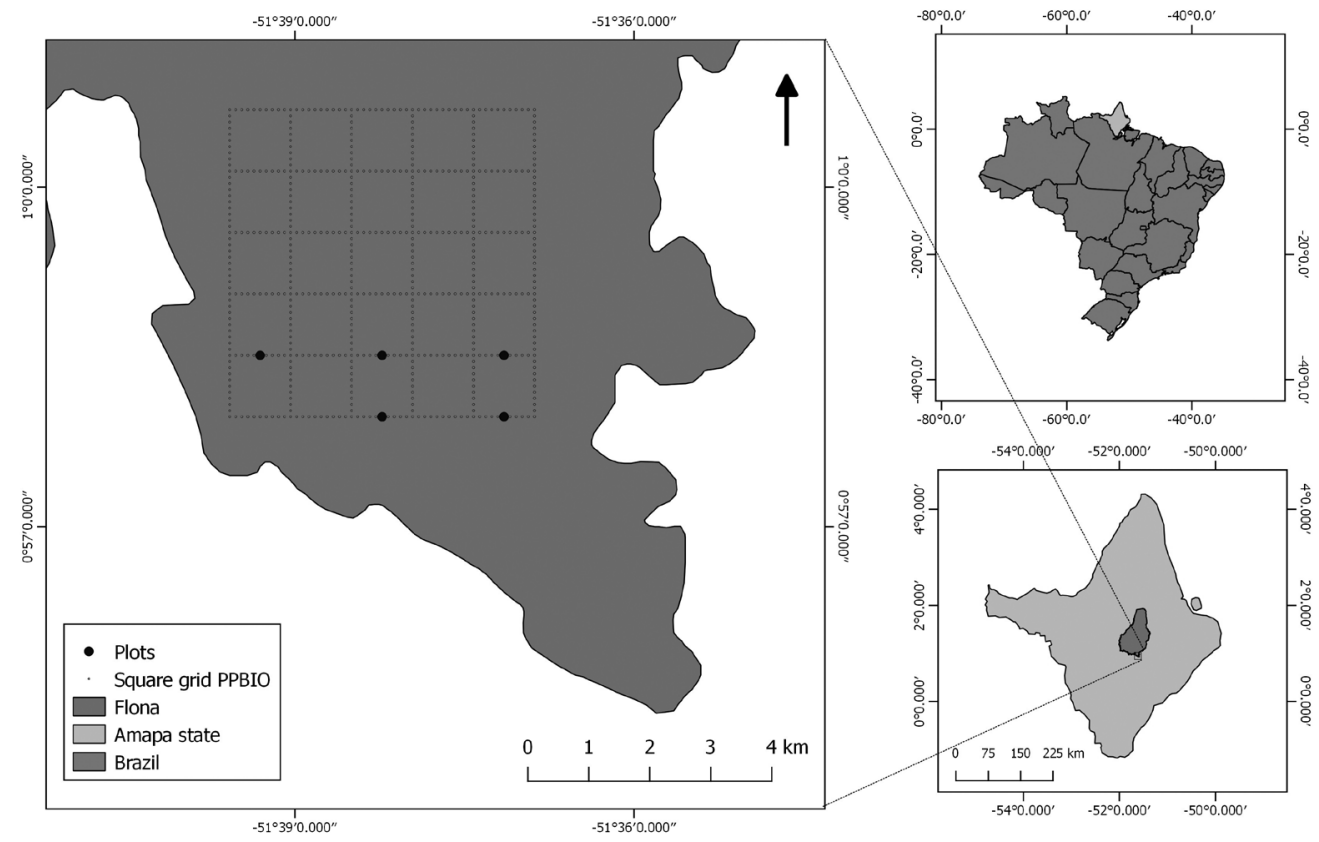

Figure 1. Location of Amapá state in Brazil, of the Amapá National Forest (ANF) (Flona in the figure legend) in Amapá, and of the 5x5-km trail grid and the five sampling plots within ANF. (Map: Bayron R. Calle Rendón).

field data clearly showed that this genus is a food resource for the animal species at the study site.

The 72 focal trees were monitored from January to September 2017, as we could not arrive at the focal trees early in the morning during the late dry season due to the low level of the river used to access the grid, which prevented navigation among surfaced rocks before dawn. We selected the focal trees so that a minimum of three and a maximum of six trees were monitored for each genus (Supplementary Material, Table S2). We observed the focal trees from 07:00 to 17:00h (sunrise varied from 6:04 to $6: 35 \mathrm{~h}$ and sunset, from 18:11 to $18: 41 \mathrm{~h}$ ). It was not possible to start monitoring earlier in the morning due to fog. Trees were observed with $10 \times 42$ binoculars. Only two observers stayed near the focal tree, in a position from where they could observe the whole tree canopy. The observers adopted a discreet posture, wore camouflage, and avoided making any sound to minimize any disturbance to the frugivores. We did not register terrestrial and/or nocturnal frugivores. We recorded the length of each feeding bout, i.e. the time between the moment that each frugivore individual or group started feeding on the fruiting tree, and the moment it/they stopped feeding or left the tree (we assume no registration bias occurred as we never observed more than one species visiting the monitored tree at the same time). We used a field guide (Sigrist 2013) to identify bird species and obtain their body length. The body length of primates was obtained from Bicca-Marques et al. (2006).

For each focal tree, we collected fallen ripe fruits (average $=3.6$ fruits per tree; standard deviation $=2.9 ;$ range $=1$ to 14 ) to measure fruit characteristics. Considering the low level of frugivory in the study site, we assume that fallen fruits may represent the average fruit traits of each tree. We used a caliper to record fruit length and width and calculated a fruit size index by multiplying fruit length by width. Fruit weight was measured with spring scales. We calculated a seed-size index by multiplying seed length by width. The smallest seeds were considered as having a size of $0.01 \mathrm{~cm}$, the smallest division of the caliper. Fruit and seed traits were averaged over the focal trees of the same species (Supplementary Material, Table S2).

\section{Statistical analyses}

To examine the mechanisms of niche segregation between frugivores and trees, we evaluated the factors that affect four dependent variables: frugivore size (average species body length), whether the seeds were swallowed or not by the frugivore species, species richness, and abundance of frugivore individuals visiting each tree. We ran generalized linear models in a multi-model inference approach in the "MuMIn" package (Barton 2009) of the R software version 3.6.3 (R Core Team 2019). We created four full models (one for each dependent variable; Supplementary Material, Table S3), including the independent variables that we hypothesized could affect the dependent variables. We then tested every possible combination of independent variables and ranked the models based on their AICc (Akaike's Information Criterion corrected for small samples). $\triangle \mathrm{AICc}$ values (the difference between the AICc of a given model and the AICc of the most parsimonious model) were used to calculate Akaike weights, which were then used to average the models and calculate 
importance values for each independent variable (Burnham and Anderson 2004). We only considered those models with a $\triangle$ AICc $\leq 2.0$. Variables were considered important when their importance value was $>4.0$ (Burnham 2015). Prior to the analyses, all continuous variables were standardized to zero mean and unit variance. Since some independent variables could be correlated, we calculated Variance Inflation Factors (VIF) with the "car" package (Fox and Weisberg 2011), using the $\mathrm{R}$ software, and excluded those models in which collinearity could represent a problem (at least one VIF > 3.0; Quinn and Keough 2002). Therefore, the model averaging approach was carried out only with collinearity-free models. The sampling units of these analyses were the feeding bouts (dependent variables: frugivore size and whether the seed was swallowed or not) or the focal trees (dependent variables: frugivore richness and abundance). We also tested if the time of arrival at the feeding tree (continuous dependent variable) differed between taxonomic groups (independent variable) through an ANOVA with Tukey's post-hoc test. Given the low number of visits for some taxonomic groups, we grouped all non-passerine birds into one category, and compared them to Passeriformes and Primates.

\section{RESULTS}

Seventy-three frugivore individuals visited the focal trees during the study. The number of frugivore individuals presented a bimodal temporal pattern, with peaks in January (17 individual frugivores) and July (20 individual frugivores) (Figure 2). The highest number of species visiting the focal trees was recorded in August and September (Figure 2). Twenty-two species (20 bird and two primate species) were recorded consuming fruit of $20(27.8 \%)$ of the 72 focal trees (Supplementary Material, Tables S2 and S4).

Frugivores observed in this study consumed only ripe fruits. The frequency of trees bearing ripe fruit was low between January and March (approximately 4\%) and tended to increase throughout the study period, reaching 18\% in August and September (Figure 2). Out of the 942 trees of zoochoric species monitored monthly, we did not detect fruit-bearing in 51\% ( $\mathrm{n}=472)$ over the course of the study. Coinciding with fruit availability, frugivory was more prevalent in August and September, when we observed fruit consumption in $40 \%$ of the focal trees.

Fruit weight, as well as seed size, were important to explain the size of the frugivores that visited the focal trees. Heavier fruits were consumed by larger frugivores, whereas seed size was inversely correlated with frugivore size (Table 2). Fruit dimension and frugivore size were important for predicting whether the seeds were swallowed or not (Table 2). Larger frugivores ingested seeds more frequently than smaller ones. Moreover, seeds of narrower and lighter fruits were also ingested more frequently. None of the independent

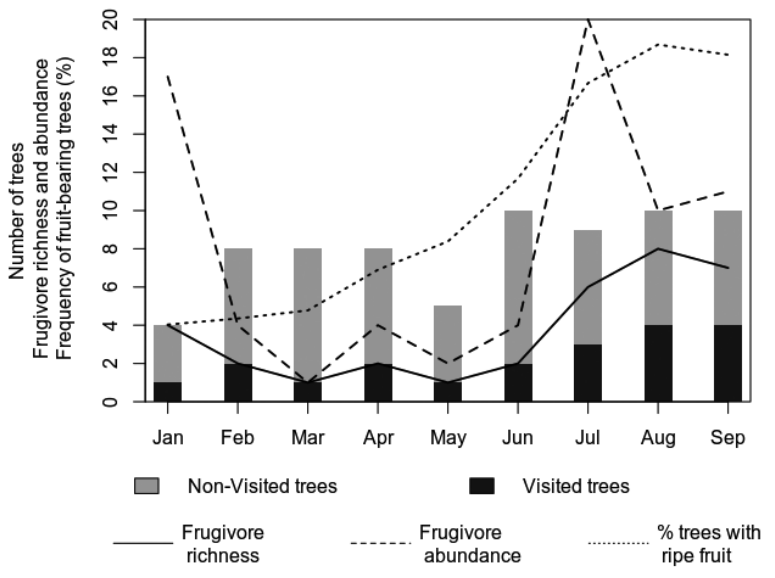

Figure 2. Monthly variation in the number of focal trees, fruit availability, and frugivore visitation in the five sampling plots during the study in Amapá National Forest (Amapá, Brazil). Bars show the number of focal trees monitored each month (visited and non-visited by frugivores). Lines show frugivore species richness (solid line), and individual abundance (dashed line) observed in the monitored trees, and the percentage of trees bearing ripe fruit in the sampling plots (dotted line).

variables tested were important for predicting the number of frugivore species that fed on the focal trees (Supplementary Material, Table S5). Nevertheless, the number of individual frugivores recorded in the focal trees was negatively related to the seed's smallest dimension (Table 2; Supplementary Material, Table S6).

Regarding temporal niche segregation between taxonomic groups, primates arrived later at the trees to forage compared to Psittaciformes and Piciformes $\left(F_{4,39}=3.771 ; p=0.011\right)$, i.e. primates visited the fruiting trees in average 4.5 hours later then Psittaciformes and Piciformes. Most (65.8\%) of the observed frugivores visited the monitored trees in the morning.

\section{DISCUSSION}

\section{Niche segregation among frugivores}

We showed that fruit traits influence which frugivores will feed on them, and affect the probability of fruits and seeds being ingested by frugivores, thus affecting seed dispersal patterns. Body size was among the most important niche segregation factors among frugivores, with larger frugivores feeding on heavier fruits due to their greater strength and larger gape (partially corroborating H1). Body size is correlated with gape size in birds, which limits the maximum fruit size that birds can swallow whole (Moran and Catterall 2010). However, sometimes frugivores can handle the fruits to eat them piecemeal, and primates and psittacids can feed on fruits much larger than their gapes (Oliveira et al. 2011; Baños-Villaba 2017). Indeed, this was the case of the two small psittacids (Brotogeris chrysoptera and Touit huetii) in our study, which fed on fruits larger than their gapes, by eating the pulp but not ingesting the seeds. Therefore, the relationship 
Table 2. Model-averaging results based on Akaike weights of the models with $\triangle \mathrm{AICC}$ (difference between the AICC of a given model and the AICC of the most parsimonious model) $\leq 2.0$. Variables were considered important for predicting frugivore size, whether the seed was swollen or not, and frugivore abundance when they presented an importance value $>0.4$. Coefficients, standard errors, and $P$-values were conditionally averaged. Coef $=$ coefficient; $I \mathrm{mp}=$ variable importance; $n a=$ not applicable; $\mathrm{DBH}=$ tree diameter at breast height; abs = variable absent from the models with $\triangle \mathrm{AIC} c \leq 2.0$. The models used in the model averaging are presented in Supplementary Material, Table S6.

\begin{tabular}{|c|c|c|c|c|c|c|c|c|c|}
\hline \multirow{2}{*}{ Independent variables } & \multicolumn{3}{|c|}{ Frugivore size } & \multicolumn{3}{|c|}{ Seed swallowed or not } & \multicolumn{3}{|c|}{ Frugivore abundance } \\
\hline & Coef \pm SE & $\mathrm{p}$ & $\operatorname{Imp}$ & Coef \pm SE & $p$ & $\operatorname{Imp}$ & Coef \pm SE & $p$ & Imp \\
\hline Fruit weight & $0.635 \pm 0.141$ & $<0.001$ & 1.00 & $-1.053 \pm 0.588$ & 0.083 & 0.90 & abs & abs & abs \\
\hline Seed size & $-0.387 \pm 0.112$ & $<0.001$ & 1.00 & $-1.988 \pm 1.444$ & 0.182 & 0.20 & abs & abs & abs \\
\hline Fruit size & abs & abs & abs & $-2.417 \pm 0.940$ & 0.013 & 0.24 & $-0.212 \pm 0.222$ & 0.375 & 0.17 \\
\hline Seed smallest dimension & abs & abs & abs & $-0.866 \pm 0.606$ & 0.166 & 0.41 & $-0.631 \pm 0.215$ & 0.006 & 1.00 \\
\hline $\mathrm{DBH}$ & $0.136 \pm 0.113$ & 0.240 & 0.38 & na & na & na & $0.137 \pm 0.154$ & 0.409 & 0.16 \\
\hline Fruit smallest dimension & abs & abs & abs & $-2.037 \pm 0.817$ & 0.015 & 0.76 & abs & abs & abs \\
\hline Frugivore size & na & na & na & $1.605 \pm 0.553$ & 0.005 & 1.00 & na & na & na \\
\hline Ripe fruit prevalence & na & na & na & na & na & na & $0.184 \pm 0.143$ & 0.231 & 0.24 \\
\hline
\end{tabular}

of frugivore size and the size of the fruits they can ingest may be dependent on the behaviour of the taxonomic group. We were not able to evaluate this relationship within taxonomic groups due to sample size.

Larger frugivores also consumed fruits with smaller seeds and swallow the seeds more frequently than smaller frugivores, a result that partially contradicts $\mathrm{H} 1$, but supports $\mathrm{H} 3$. This pattern is probably linked with the fact that they swallow the whole fruit instead of discarding the seeds (Jordano 2000; Jordano and Schupp 2000), and that frugivores maximize the pulp:seed ratio, preferring large fruits with small seeds (Blendinger et al. 2016). Also, although many studies detected a positive relationship between frugivore size and the seed size they ingest (e.g. Moran and Catterall 2010; Burns 2013; Galetti et al. 2013), a recent study with a larger data set actually revealed a negative relationship, which confirms our findings (Chen and Moles 2015). By ingesting seeds more frequently, larger frugivores disperse the seeds of a larger array of plants than smaller ones (Moran and Catterall 2010; Chen and Moles 2015). Larger body sizes may be advantageous for gapeconstrained frugivores, allowing them to feed on a wider range of fruits (Moran and Catterall 2010; Chen and Moles 2015; this study). Conversely, larger frugivores also have a higher energetic demand, which poses a challenge, especially during periods of fruit scarcity, when they must rely on alternative food sources (Hawes and Peres 2014). Nonetheless, larger frugivores, such as ramphastids and primates, accounted for $38 \%$ of the feeding bouts in our study, highlighting the role of these groups in the maintenance and structuring of biodiversity in tropical forests.

In addition to morphology, timing was also a niche segregation dimension among frugivores in our study. Birds visited fruiting trees earlier than primates during the day, obtaining a competitive advantage (supporting H9). Indeed, most frugivory occurs in the morning, when frugivores feed on the fruits that ripened overnight (Daily and Ehrlich 1994; Graham et al. 2002). Besides food availability and environmental factors (Bruni et al. 2014), an animal's activity onset also depends on physiological factors (Taufique et al. 2016) and predation risk (Saggese et al. 2011), which may explain the differences between primates and birds.

Time is also a niche segregation factor between diurnal and nocturnal frugivores, although we were not able to analyze the latter in this study. Nocturnal canopy frugivores at our study site include bats, marsupials, and kinkajous (IEPA/CI 2006), and the amount of fruit consumed by these frugivores during the night may affect the scale of the advantage of birds in consuming fruit earlier in the morning, in spite of their arriving earlier to feed than primates. However, the fruit consumed by nocturnal and diurnal frugivores generally differ morphologically and chemically (Korine et al. 2000; Albuquerque et al. 2006), and a limited proportion of the plants are exploited by both diurnal and nocturnal frugivores (Mello et al. 2011). Considering this, our conclusions are, therefore, limited to diurnal canopy frugivores.

\section{Niche segregation among trees}

Fruit morphology influences seed dispersal (Galetti et al. 2013), which is an important niche dimension related to plant reproductive success. We found that fruit morphology (weight and seed size) is a niche segregation mechanism among zoochoric trees at ANF, a pattern that corroborates our hypotheses H1, H4, H5 and H6. Trees may influence the size of frugivores that visit them through the weight of the fruit and the size of the seeds. By influencing the size of the frugivores, trees may also influence seed dispersal distance, since larger dispersers are often involved in greater 
seed dispersal distances (Jordano et al. 2007; Wotton and Kelly 2012). Producing smaller fruits can also maximize seed ingestion and, consequently, dispersal.

The number of frugivores that visit trees may also be increased through seed size (H6). The increased visitation of trees with small seeds may have been related to a frugivore preference for feeding on fruits that maximize the pulp:seed ratio. Large seeds occupy greater volumes in the gut, limiting the amount of pulp that a frugivore can ingest and digest, and/or speeding up gut transit time, which reduces fruit digestibility (Jordano 2000). Besides morphological aspects of fruits and seeds, there are other ways in which plants can influence fruit selection by frugivores, such as the nutritional content of the fruits, olfactory cues, and timing of fructification (Cazetta et al. 2008; Leiner et al. 2009), which were not evaluated in our study.

\section{Comparison with previous studies}

Most studies evaluating frugivory consider only relatively few species (Russo 2003; McConkey et al. 2014; Moreira et al. 2017; Pegman et al. 2017), which limits the understanding of frugivory intensity throughout entire biological communities, particularly in the highly diverse tropical forests. Two exceptions are studies that registered a high intensity of frugivory at the community level in tropical rainforests in Kenya (Kakamega Forest - KF) (Flörchinger et al. 2010) and the Colombian Amazon in the Tinigua National Park TNP (Stevenson et al. 2015). We observed a lower level of visitation by frugivores in our focal trees than that reported by the latter studies. Sampling effort was equivalent in the three studies, yet the number of frugivores recorded per hour of monitoring was much higher in Kenya and Colombia. Therefore, sampling effort cannot explain our lower figures. In addition, the proportion of zoochoric trees bearing fruits throughout the year does not seem to vary significantly between ANF and TNP (Stevenson 2004). We did not find any comparable data on fruit availability in the KF. Frugivore densities may explain the differences between ANF and the other sites. However, although the density of spider monkeys (Ateles spp.) is lower in ANF than in TNP (Stevenson 1996; Michalski et al. 2017), no comparable information exists on the densities of other frugivores. Although low densities of frugivores may explain the low level of frugivory in ANF, this hypothesis remains to be tested.

The study at KF also examined niche segregation factors at the community level (Flörchinger $e t$ al. 2010). Although these authors investigated different factors and used a different analytical approach, some comparison can still be made between both studies. Plant height, fruit crop mass, fruit size, and fruit color affected which frugivores visited each tree in KF. Other two studies used different approaches and found that frugivore size and fruit size affected fruit consumption positively and negatively, respectively, in the Andean forests of Colombia (Muñoz et al. 2016), and that frugivore traits, such as size, are related to plant traits, such as plant height and fruit size in the Andean forests of Peru (Dehling et al. 2016). Thus, all these studies agree with our findings that tree size and fruit morphology are niche segregation mechanisms among zoochoric trees, and that body size is a niche segregation mechanism among frugivores. In addition, our study also showed that the time of day in which frugivores feed is a niche segregation mechanism among diurnal canopy frugivores.

\section{CONCLUSIONS}

We found that body size is a niche segregation factor among vertebrate canopy frugivores in Amapá National Forest, being related to the size and weight of the fruit consumed, and seed ingestion, which is essential for seed dispersal. Frugivores also differed in the time of day they visited fruiting trees, which may represent an advantage to birds, which visit the trees earlier than primates. Plant traits, such as fruit weight and seed size, also influenced which frugivore species and the abundance of individuals that visit a given fruiting tree, with potential consequences for the success of seed dispersal. Despite the high number of focal trees sampled in this study, the low level of visitation by frugivores at ANF resulted in a small sample size. This small sample size prevented more complex analyses, such as ecological networks, and may have prevented the detection of some relationships among variables. Nevertheless, our results corroborate most of our hypotheses and seem to be robust, both statistically and in view of their ecological sense. At our study site, frugivore size, time of day of tree visitation by frugivores, and plant traits seem to be important niche segregation mechanisms, which may also be crucial determinants in other Amazonian biological communities.

\section{ACKNOWLEDGMENTS}

We are thankful to Coordenaçáo de Aperfeiçoamento de Pessoal de Nivel Superior - CAPES (Brazil) for the scholarships to FT and RRH (Process \# 88881.314420/2019-01). This study was carried out with the support of Conselho Nacional de Desenvolvimento Científico e Tecnológico - CNPq (Brazil) (Process \# 447432/2014-1). LMR was financially supported by Centro de Ecologia, Evolução e Alteraçôes Ambientais - cE3c (Portugal) (Process \# UID/BIA/00329/2019) and Fundação para a Ciência e a Tecnologia - FCT/MCTES (Portugal) through national funds, and co-funding by FEDER, within the PT2020 Partnership Agreement and Compete 2020. We are grateful to Instituto Chico Mendes de Conservação da Biodiversidade - ICMBio (Brazil) for the permit and all the ANF staff for their support in fieldwork. We also thank Universidade Federal do Amapá for help with transportation. Finally, we are grateful to two anonymous 
reviewers, who contributed with valuable suggestions on an earlier version of the manuscript.

\section{REFERENCES}

Albuquerque, L.B.; Velázquez, A.; Mayorga-Saucedo, R. 2006. Solanaceae composition, pollination and seed dispersal syndromes in Mexican Mountain Cloud Forest. Acta Botanica Brasilica, 20: 599-613.

Baños-Villalba, A.; Blanco, G.; Díaz-Luque, J.A.; Dénes, F.V.; Hiraldo, F; Tella, J.L. 2017. Seed dispersal by macaws shapes the landscape of an Amazonian ecosystem. Scientific Reports, 7: 1-12.

Barton, K. 2009. MuMIn: multi-model inference. R package version 1.0.0.

Bello, C.; Galetti, M.; Pizo, M.A.; Magnago, L.F.S.; Rocha, M.F.; Lima, R.A.; Jordano, P. 2015. Defaunation affects carbon storage in tropical forests. Science Advances, 1: e1501105.

Bersacola, E.; Svensson, M.S.; Bearder, S.K. 2015. Niche partitioning and environmental factors affecting abundance of strepsirrhines in Angola. American Journal of Primatology, 77: 1179-1192.

Bicca-Marques, J.C.; Silva, V.M.; Gomes, D. 2006. Ordem Primates. In: Reis, N.R.; Peracchi, A.L.; Pedro, W.A.; Lima, I.P. (Ed.). Mamiferos do Brasil. Edifurb/UEL, Londrina, p.107-150.

Blendinger, P.G.; Martín, E.; Osinaga, A.O.; Ruggera, R.A.; Aráoz, E. 2016. Fruit selection by Andean forest birds: influence of fruit functional traits and their temporal variation. Biotropica, 48: 677-686.

Bruni, A.; Mennill, D.J.; Foote, J.R. 2014. Dawn chorus start time variation in a temperate bird community: relationships with seasonality, weather, and ambient light. Journal of Ornithology, 155: 877-890.

Burnham, K.P. 2015. Multimodel Inference: Understanding AIC relative variable importance values. (https://sites. warnercnr.colostate.edu/kenburnham/wp-content/uploads/ sites/25/2016/08/VARIMP.pdf). Accessed on 19 Oct 2019.

Burnham, K.P.; Anderson, D.R. 2004. Multimodel inference: understanding AIC and BIC in model selection. Sociological Methods \& Research, 33: 261-304.

Burns, K.C. 2013. What causes size coupling in fruit-frugivore interaction webs? Ecology, 94: 295-300.

Byng, J.W.; Chase, M.W.; Christenhusz, M.J.M.; Fay, M.F.; Judd, W.S.; Mabberley, D.J.; Sennikov, A.N.; Soltis, D.E.; Soltis, P.S.; Stevens, P.F. 2016. An update of the Angiosperm Phylogeny Group classification for the orders and families of flowering plants: APG IV. Botanical Journal of the Linnean Society, 181: $1-20$.

Camargo, P.H.; Rodrigues, S.B.; Piratelli, A.J.; Oliveira, P.S.; Christianini, A.V. 2019. Interhabitat variation in diplochory: Seed dispersal effectiveness by birds and ants differs between tropical forest and savanna. Perspectives in Plant Ecology, Evolution and Systematics, 38: 48-57.

Cazetta, E.; Schaefer, H.M.; Galetti, M. 2008. Does attraction to frugivores or defense against pathogens shape fruit pulp composition? Oecologia, 155: 277-286.
Chapman, C.A.; Chapman, L.J.; Wangham, R.; Hunt, K.; Gebo, D.; Gardner, L. 1992. Estimators of fruit abundance of tropical trees. Biotropica, 24: 527-531.

Chase, J.M.; Leibold, M.A. 2003. Ecological Niches: Linking Classical and Contemporary Approaches. University of Chicago Press, Chicago, 212p.

Chen, S.C.; Moles, A.T. 2015. A mammoth mouthful? A test of the idea that larger animals ingest larger seeds. Global Ecology and Biogeography, 24: 1269-1280.

Chesson, P. 2000. Mechanisms of maintenance of species diversity. Annual Review of Ecology and Systematics, 31: 343-366.

Daily, G.C.; Ehrlich, P.R. 1994. Influence of social status on individual foraging and community structure in a bird guild. Oecologia, 100: 153-165.

Dehling, D.M.; Jordano, P.; Schaefer, H.M.; Böhning-Gaese, K. Schleuning, M. 2016. Morphology predicts species functional roles and their degree of specialization in plant-frugivore interactions. Proceedings of the Royal Society B, 283: 20152444.

Fleming, T.H.; Kress, W.J. 2011. A brief history of fruits and frugivores. Acta Oecologica, 37: 521-530.

Flörchinger, M.; Braun, J.; Böhning-Gaese, K.; Schaefer, H.M. 2010. Fruit size, crop mass, and plant height explain differential fruit choice of primates and birds. Oecologia, 164: 151-161.

Fox, J.; Weisberg, S. 2011. An R companion to applied regression. Sage Publications, Los Angeles, 608p.

Fricke, E.C.; Simon, M.J.; Reagan, K.M.; Levey, D.J.; Riffell, J.A.; Carlo, T.A.; Tewksbury, J.J. 2013. When condition trumps location: seed consumption by fruiteating birds removes pathogens and predator attractants. Ecology Letters, 16: $1031 \mathrm{e} 1036$.

Galetti, M.; Guevara, R.; Côrtes, M.C.; Fadini, R.; Von Matter, S.; Leite, A.B.; et al. 2013. Functional extinction of birds drives rapid evolutionary changes in seed size. Science, 340: 1086-1090.

Gardner, C.J.; Bicknell, J.E.; Baldwin-Cantello, W.; Struebig, M.J.; Davies, Z.G. 2019. Quantifying the impacts of defaunation on natural forest regeneration in a global meta-analysis. Nature Communications, 10: 1-7.

Graham, C.; Martínez-Leyva, J.E.; Cruz-Paredes, L. 2002. Use of fruiting trees by birds in continuous forest and riparian forest remnants in Los Tuxtlas, Veracruz, Mexico. Biotropica, 34: 589-597.

Günter, S.; Stimm, B.; Cabrera, M.; Diaz, M.L.; Lojan, M.; Ordoñez, E.; Richter, M.; Weber, M. 2008. Tree phenology in montane forests of southern Ecuador can be explained by precipitation, radiation and photoperiodic control. Journal of Tropical Ecology, 24: $247-258$.

Hawes, J.E.; Peres, C.A. 2014. Ecological correlates of trophic status and frugivory in neotropical primates. Oikos, 123: 365-377.

Herrera, C.M. 2002. Seed dispersal by vertebrates. In: Herrera, C.M.; Pellmyr, O. (Ed.). Plant-Animal Interactions: an Evolutionary Approach. Blackwell, Oxford, p.185-208.

ICMBio. 2014. Plano de Manejo da Floresta Nacional do Amapá, Volume I-Diagnóstico. ICMBio, Macapá, 222p. 
IEPA/CI. 2006. Inventários Biológicos na Floresta Nacional do AmapáExpediçôes I e II. Instituto de Pesquisas Científicas e Tecnológicas do Estado do Amapá-IEPA/Conservação Internacional, Macapá. Unpublished technical report. $128 \mathrm{p}$

Jordaan, L.A.; Johnson, S.D.; Downs, C.T. 2011. The role of avian frugivores in germination of seeds of feshyfruited invasive alien plants. Biological Invasions, 13: 1917-1930.

Jordano, P. 2000. Fruits and frugivory. In: Fenner, M. (Ed.). Seeds: the Ecology of Regeneration in Plant Communities. CABI Publishing, Wallingford, p.125-166.

Jordano, P.; Garcia, C.; Godoy, J.A.; García-Castaño, J.L. 2007. Differential contribution of frugivores to complex seed dispersal patterns. Proceedings of the National Academy of Sciences USA, 104: 3278-3282.

Jordano, P.; Schupp, E.W. 2000. Seed disperser effectiveness: the quantity component and patterns of seed rain for Prunus mahaleb. Ecological Monographs, 70: 591-615.

Korine, C.; Kalko, E.K.; Herre, E.A. 2000. Fruit characteristics and factors affecting fruit removal in a Panamanian community of strangler figs. Oecologia, 123: 560-568.

Kraft, N.J.B.; Valencia, R.; Ackerly, D.D. 2008. Functional traits and niche-based tree community assembly in an Amazonian forest. Science, 322: 580-582.

Leiner, N.O.; Nascimento, A.R.; Melo, C. 2009. Plant strategies for seed dispersal in tropical habitats: patterns and implications. In: del Claro, K.; Oliveira, P.S.; Rico-Gray, V. (Ed.). Tropical Biology and Conservation Management: Natural History of Tropical Plants. v. 1. Eolss Publishers, Oxford, p.155-170.

Lewis, S.L.; Edwards, D.P.; Galbraith, D. 2015. Increasing human dominance of tropical forests. Science, 349: 827-832.

Lomáscolo, S.B.; Levey, D.J.; Kimball, R.T.; Bolker, B.M.; Alborn, H.T. 2010. Dispersers shape fruit diversity in Ficus (Moraceae). Proceedings of the National Academy of Sciences, 107: 14668-14672.

McConkey, K.R.; Brockelman, W.Y.; Saralamba, C. 2014. Mammalian frugivores with different foraging behavior can show similar seed dispersal effectiveness. Biotropica, 46: 647-651.

Mello, M.A.R.; Marquitti, F.M.D.; Guimarães, P.R.; Kalko, E.K.V.; Jordano, P.; Aguiar, M.A.M. 2011. The modularity of seed dispersal: differences in structure and robustness between batand bird-fruit networks. Oecologia, 167: 131 (doi.org/10.1007/ s00442-011-1984-2).

Michalski, F.; Michalski, L.J.; Barnett, A.A. 2017. Environmental determinants and use of space by six Neotropical primates in the northern Brazilian Amazon. Studies on Neotropical Fauna and Environment, 52: 187-197.

Moran, C.; Catterall, C.P. 2010. Can functional traits predict ecological interactions? A case study using rain forest frugivores and plants in Australia. Biotropica, 42: 318-326.

Moreira, J.I.; Riba-Hernández, P.; Lobo, J.A. 2017. Toucans (Ramphastos ambiguus) facilitate resilience against seed dispersal limitation to a large-seeded tree (Virola surinamensis) in a humanmodified landscape. Biotropica, 49: 502-510.
Mubo, S.A.; Adeniyi, J.A.; Adeyemi, E. 2004. A morphometric analysis of the genus Ficus Linn. (Moraceae). African Journal of Biotechnology, 3: 229-235.

Munguía-Rosas, M.A.; Ollerton, J.; Parra-Tabla, V.; De-Nova, J.A. 2011. Meta-analysis of phenotypic selection on flowering phenology suggests that early flowering plants are favoured. Ecology Letters, 14: 511-521.

Muñoz, M.C.; Schaefer, H.M.; Böhning-Gaese, K.; Schleuning, M. 2017. Importance of animal and plant traits for fruit removal and seedling recruitment in a tropical forest. Oikos, 126: 823-832.

Oliveira, L.C.; Neves, L.G.; Raboy, B.E.; Dietz, J.M. 2011. Abundance of jackfruit (Artocarpus heterophyllus) affects group characteristics and use of space by golden-headed lion tamarins (Leontopithecus chrysomelas) in cabruca agroforest. Environmental Management, 48: 248-262.

Pegman, A.P.M.; Perry, G.L.W.; Clout, M.N. 2017. Exploring the interaction of avian frugivory and plant spatial heterogeneity and its effect on seed dispersal kernels using a simulation model. Ecography, 40: 1098-1109.

Pizo, M.A.; Galetti, M. 2000. Métodos e perspectivas do estudo da frugivoria e dispersão de sementes por aves. In: Matter, V.S.; Straube, F.C.; Piacentini, V.Q.; Accordi, I.A.; Cândido, J.F.J. (Ed.). Ornitologia e Conservação: Ciência Aplicada, Técnicas de Pesquisa e Levantamento. Technical Books Editora Ltda, Rio de Janeiro, p.1-12.

Poulsen, J.R.; Clark, C.J.; Connor, E.F.; Smith, T.B. 2002. Differential resource use by primates and hornbills: implications for seed dispersal. Ecology, 83: 228-240.

Quinn, G.P.; Keough, M.J. 2002. Experimental Design and Data Analysis for Biologists. Cambridge University Press, New York, $537 \mathrm{p}$.

R Core Team. 2019. R: A language and environment for statistical computing. Version 3.6.2. R Foundation for Statistical Computing, Vienna.

Reis, N.R.; Peracchi, A.L.; Pedro, W.A. Lima, I.P. 2006. Mamíferos do Brasil. Edifurb/UEL, Londrina, 437p.

Rosalino, L.M.; Rosa, S.; Santos-Reis, M. 2010. The role of carnivores as Mediterranean seed dispersers. Annales Zoologici Fennici, 47: 195-205.

Russo, S.E. 2003. Responses of dispersal agents to tree and fruit traits in Virola calophylla (Myristicaceae): Implications for selection. Oecologia, 136: 80-87.

Saggese, K.; Korner-Nievergelt, F.; Slagsvold, T.; Amrhein, V. 2011. Wild bird feeding delays start of dawn singing in the great tit. Animal Behaviour, 81: 361-365.

Saracco, J.F.; Collazo, J.A.; Groom, M.J.; Carlo, T.A. 2005 Crop size and fruit neighborhood effects on bird visitation to fruiting Schefflera morototoni trees in Puerto Rico. Biotropica, 37: 81-87.

Sekar, N.; Sukumar, R. 2013. Waiting for Gajah: an elephant mutualist's contingency plan for an endangered megafaunal disperser. Journal of Ecology, 101: 1379-1388.

Sick, H. 1997. Ornitologia Brasileira. Nova Fronteira, Rio de Janeiro, $862 \mathrm{p}$.

Sigrist, T. 2013. Avifauna Brasileira: Guia de Campo. Avis Brasilis Editora, São Paulo, 591p. 
Silvertown, J. 2004. Plant coexistence and the niche. Trends in Ecology \& Evolution, 19: 605-611.

Stevenson, P.R. 1996. Censos diurnos de mamíferos y algunas aves de gran tamaño en el Parque Nacional Tinigua, Colombia. Universitas Scientiarum, 3: 67-81.

Stevenson, P.R. 2004. Phenological patterns of woody vegetation at Tinigua Park, Colombia: methodological comparisons with emphasis on fruit production. Caldasia, 26: 125-150.

Stevenson, P.R.; Link, A.; González-Caro, S.; Torres-Jiménez, M.F. 2015. Frugivory in canopy plants in a western Amazonian forest: dispersal systems, phylogenetic ensembles and keystone plants. PLoS ONE, 10: e 0140751.

Stevenson, P.R.; Quiñones, M.J.; Ahumada, J.A. 2000. Influence of fruit availability on ecological overlap among four neotropical primates at Tinigua National Park, Colombia 1. Biotropica, 32: 533-544.

Svenning, J.C. 2001. On the role of microenvironmental heterogeneity in the ecology and diversification of neotropical rain-forest palms (Arecaceae). Botanical Review, 67: 1-53.

Taufique, S.T.; Jha, N.A.; Kumar, V. 2016. Circadian rhythm determines the timing of activity, and ingestive and grooming behaviours in Indian house crows, Corvus splendens. Current Science, 110: 897-901.

Traveset, A.; Robertson, A.W.; Rodríguez-Pérez, J. 2007. A review on the role of endozoochory on seed germination. In: Schupp,
E.W.; Green, R.J.; Westcott, D.A.; Dennis, A.J. (Ed.). Seed Dispersal, Theory and its Application in a Changing World. CAB International, Wallingford, p.78-103.

Uriarte, M.; Anciães, M.; Silva, M.T.B.; Rubim, P.; Johnson, E.; Bruna, E.M. 2011. Disentangling the drivers of reduced longdistance seed dispersal by birds in an experimentally fragmented landscape. Ecology, 92: 924-937.

Vander Wall, S.B.; Longland, W.S. 2004. Diplochory: are two seed dispersers better than one? Trends in Ecology \& Evolution, 19: 155-161.

Warren, R.J.; Giladi, I. 2014. Ant-mediated seed dispersal: a few ant species (Hymenoptera: Formicidae) benefit many plants. Myrmecological News, 20: 129-140.

Wotton, D.M.; Kelly, D. 2012. Do larger frugivores move seeds further? Body size, seed dispersal distance, and a case study of a large, sedentary pigeon. Journal of Biogeography, 39: 1973-1983.

Zamora, R. 2000. Functional equivalence in plant-animal interactions: ecological and evolutionary consequences. Oikos, 88: 442-447.

RECEIVED: 06/03/2020

ACCEPTED: $21 / 06 / 2020$

ASSOCIATE EDITOR: Paulo E. Bobrowiec

\section{ERRATA}

In the above article, one of the referred species was not cited according to its latest taxonomical status.

Therefore, in the Supplementary Material, Table S1, line 3

Where it reads:

"Cebus apella":

Please read as:

"Sapajus apella"

The updated taxonomy follows:

Quintela, F.; da Rosa, C.A.; Feijó, A. 2020. Updated and annotated checklist of recent mammals from Brazil. Anais da Academia Brasileira de Ciências, 92: e20191004.

Acta Amazonica 50(4): 367-367 


\section{SUPPLEMENTARY MATERIAL (only available in the electronic version)}

Todeschini et al. Niche differentiation mechanisms among canopy frugivores and zoochoric trees in the northeastern extreme of the Amazon

Table S1. List of diurnal mammal and bird species that include fruits in their diet, with confirmed presence in the Amapá National Forest, Amapá, Brazil. We highlight whether they were observed feeding during the study. We did not include terrestrial birds and mammals (Reis et al. 2006; Sick 1997). Body length for mammals is considered without the tail and was obtained from Reis et al. (2006), and for birds it includes the tail and was obtained from Sick (1997).

\begin{tabular}{|c|c|c|c|c|}
\hline Class & Family & Species & $\begin{array}{l}\text { Body } \\
\text { length } \\
(\mathrm{cm})\end{array}$ & $\begin{array}{l}\text { Observed } \\
\text { in the } \\
\text { study }\end{array}$ \\
\hline Mammalia & Callitrichidae & Saguinus midas & 38.5 & $x$ \\
\hline Mammalia & Cebidae & Saimiri sciureus & 25.3 & \\
\hline Mammalia & Cebidae & Cebus apella & 41.9 & \\
\hline Mammalia & Cebidae & Cebus olivaceus & 41.9 & \\
\hline Mammalia & Atelidae & Alouatta seniculus & 52.5 & \\
\hline Mammalia & Atelidae & Ateles paniscus & 54.0 & $x$ \\
\hline Mammalia & Pitheciidae & Chiropotes satanas & 40.35 & \\
\hline Mammalia & Pitheciidae & Pithecia pithecia & 39.0 & \\
\hline Mammalia & Bradypodidae & Choloepus didactylus & 73.0 & \\
\hline Mammalia & Mustelidae & Eirabarbara & 62.0 & \\
\hline Mammalia & Procyonidae & Nasua nasua & 52.0 & \\
\hline Mammalia & Procyonidae & Potus flavus & 59.5 & \\
\hline Mammalia & Sciuridae & Sciurillus pusilis & 9.8 & \\
\hline Mammalia & Sciuridae & Sciurus aestuans & 20.0 & \\
\hline Aves & Psittacidae & Ara ararauna & 80.0 & \\
\hline Aves & Psittacidae & Aramacao & 89.0 & \\
\hline Aves & Psittacidae & Ara chloropterus & 90.0 & \\
\hline Aves & Psittacidae & Forpus sclateri & 12.0 & \\
\hline Aves & Psittacidae & Brotogeris versicolurus & 21.5 & \\
\hline Aves & Psittacidae & Brotogeris chrysoptera & 17.5 & $x$ \\
\hline Aves & Psittacidae & Touit purpuratus & 17.0 & $x$ \\
\hline Aves & Psittacidae & Pionopsitta barrabandi & 24.0 & \\
\hline Aves & Psittacidae & Pionopsitta caica & 23.0 & \\
\hline Aves & Psittacidae & $\begin{array}{c}\text { Graydidascalus } \\
\text { brachyurus }\end{array}$ & 22.0 & \\
\hline Aves & Psittacidae & Pionus menstruus & 27.0 & \\
\hline Aves & Psittacidae & Pionus fuscus & 26.0 & \\
\hline Aves & Psittacidae & Amazona amazonica & 34.0 & \\
\hline Aves & Psittacidae & Amazona farinosa & 40.0 & \\
\hline Aves & Psittacidae & Deroptyus accipitrinus & 43.0 & \\
\hline Aves & Cracidae & Ortalis motmot & 49.0 & \\
\hline Aves & Cracidae & Penelope marail & 64.0 & \\
\hline Aves & Cracidae & Pipile cumanensis & 74.0 & \\
\hline Aves & Cracidae & Craxalector & 90.0 & \\
\hline Aves & Odontophoridae & Odontophorus gujanensis & 26.5 & \\
\hline Aves & Psophiidae & Psophia crepitans & 48.5 & \\
\hline Aves & Falconidae & Daptrius ater & 41.0 & \\
\hline Aves & Falconidae & Ibycter americanus & 54.5 & \\
\hline Aves & Rallidae & Aramides cajanea & 39.0 & \\
\hline Aves & Rallidae & Laterallus viridis & 18.0 & \\
\hline Aves & Columbidae & Patagioenas speciosa & 30.0 & \\
\hline Aves & Columbidae & Patagioenas cayennensis & 26.0 & \\
\hline
\end{tabular}

Table S1. Continued.

\begin{tabular}{|c|c|c|c|c|}
\hline Class & Family & Species & $\begin{array}{l}\text { Body } \\
\text { length } \\
(\mathrm{cm})\end{array}$ & $\begin{array}{c}\text { Observed } \\
\text { in the } \\
\text { study }\end{array}$ \\
\hline Aves & Columbidae & Patagioenas plumbea & 34.0 & \\
\hline Aves & Columbidae & Patagioenas subvinacea & 29.0 & \\
\hline Aves & Columbidae & Leptotila verreauxi & 26.5 & \\
\hline Aves & Columbidae & Geotrygon montana & 24.0 & \\
\hline Aves & Cuculidae & Crotophaga ani & 36.0 & \\
\hline Aves & Cuculidae & Piaya cayana & 47.0 & \\
\hline Aves & Trogonidae & Trogon viridis & 30.0 & \\
\hline Aves & Trogonidae & Trogon violaceus & 22.0 & \\
\hline Aves & Trogonidae & Trogon melanurus & 31.5 & $x$ \\
\hline Aves & Momotidae & Momotus momota & 44.0 & \\
\hline Aves & Bucconidae & Bucco tamatia & 17.0 & \\
\hline Aves & Ramphastidae & Ramphastos tucanus & 55.0 & \\
\hline Aves & Ramphastidae & Ramphastos vitellinus & 46.0 & $x$ \\
\hline Aves & Ramphastidae & Selenidera culik & 33.0 & \\
\hline Aves & Ramphastidae & Pteroglossus viridis & 33.0 & $x$ \\
\hline Aves & Ramphastidae & Pteroglossus aracari & 43.0 & \\
\hline Aves & Ramphastidae & Selenidera piperivora & 34.0 & $x$ \\
\hline Aves & Picidae & Veniliornis passerinus & 15.0 & \\
\hline Aves & Picidae & Celeus grammicus & 20.0 & \\
\hline Aves & Picidae & Celeus flavescens & 27.0 & \\
\hline Aves & Picidae & Dryocopus lineatus & 33.0 & \\
\hline Aves & Picidae & Campephilus rubricollis & 34.0 & \\
\hline Aves & Picidae & Piculus flavigula & 19.5 & $x$ \\
\hline Aves & Grallariidae & Grallaria varia & 19.5 & \\
\hline Aves & Tyrannidae & Mionectes macconnelli & 11.5 & \\
\hline Aves & Tyrannidae & Tyrannulus elatus & 10.5 & \\
\hline Aves & Tyrannidae & Myiopagis gaimardii & 12.5 & \\
\hline Aves & Tyrannidae & Elaenia flavogaster & 15.0 & \\
\hline Aves & Tyrannidae & Pitangus sulphuratus & 22.5 & \\
\hline Aves & Tyrannidae & Tyrannus albogularis & 20.0 & \\
\hline Aves & Tyrannidae & Tyrannus melancholicus & 21.5 & \\
\hline Aves & Tyrannidae & Myiarchus ferox & 19.5 & \\
\hline Aves & Tyrannidae & Attila spadiceus & 17.0 & \\
\hline Aves & Cotingidae & Phoenicircus carnifex & 21.0 & \\
\hline Aves & Cotingidae & Cotinga cotinga & 18.0 & \\
\hline Aves & Cotingidae & Procnias albus & 28.0 & \\
\hline Aves & Cotingidae & Lipaugus vociferans & 24.0 & $x$ \\
\hline Aves & Cotingidae & Xipholena punicea & 19.0 & \\
\hline Aves & Cotingidae & Querula purpurata & 27.0 & \\
\hline Aves & Cotingidae & Perissocephalus tricolor & 35.0 & \\
\hline Aves & Pipridae & Corapipo gutturalis & 8.6 & \\
\hline Aves & Pipridae & Lepidothrix serena & 8.7 & \\
\hline Aves & Pipridae & Manacus manacus & 11.0 & \\
\hline Aves & Pipridae & Dixiphia pipra & 10.0 & \\
\hline Aves & Pipridae & Pipra aureola & 10.5 & \\
\hline Aves & Pipridae & Pipra erythrocephala & 11.0 & \\
\hline
\end{tabular}


Table S1. Continued

\begin{tabular}{|c|c|c|c|c|}
\hline Class & Family & Species & $\begin{array}{c}\text { Body } \\
\text { length } \\
(\mathrm{cm})\end{array}$ & $\begin{array}{l}\text { Observed } \\
\text { in the } \\
\text { study }\end{array}$ \\
\hline Aves & Tityridae & Schiffornis turdina & 16.0 & \\
\hline Aves & Tityridae & Laniocera hypopyrra & 20.7 & \\
\hline Aves & Tityridae & Tityra cayana & 21.0 & \\
\hline Aves & Corvidae & Cyanocorax cayanus & 33.0 & \\
\hline Aves & Troglodytidae & Cyphorhinus arada & 12.6 & \\
\hline Aves & Turdidae & Turdus leucomelas & 22.0 & \\
\hline Aves & Turdidae & Turdus fumigatus & 24.0 & $x$ \\
\hline Aves & Turdidae & Turdus albicollis & 22.0 & $x$ \\
\hline Aves & Coerebidae & Coereba flaveola & 10.8 & \\
\hline Aves & Thraupidae & $\begin{array}{l}\text { Lamprospiza } \\
\text { melanoleuca }\end{array}$ & 15.5 & \\
\hline Aves & Thraupidae & Eucometis penicillata & 18.0 & \\
\hline Aves & Thraupidae & Tachyphonus cristatus & 15.5 & \\
\hline Aves & Thraupidae & Tachyphonus surinamus & 15.5 & \\
\hline Aves & Thraupidae & Tachyphonus luctuosus & 12.5 & \\
\hline Aves & Thraupidae & Tachyphonus rufus & 18.0 & $x$ \\
\hline Aves & Thraupidae & Tachyphonus phoenicius & 15.5 & \\
\hline Aves & Thraupidae & Lanio fulvus & 18.0 & $x$ \\
\hline Aves & Thraupidae & Ramphocelus carbo & 18.0 & $x$ \\
\hline
\end{tabular}

Table S1. Continued.

\begin{tabular}{|c|c|c|c|c|}
\hline Class & Family & Species & $\begin{array}{l}\text { Body } \\
\text { length } \\
(\mathrm{cm})\end{array}$ & $\begin{array}{l}\text { Observed } \\
\text { in the } \\
\text { study }\end{array}$ \\
\hline Aves & Thraupidae & Thraupis episcopus & 16.5 & \\
\hline Aves & Thraupidae & Thraupis palmarum & 18.0 & \\
\hline Aves & Thraupidae & Tangara chilensis & 13.5 & \\
\hline Aves & Thraupidae & Tangara punctata & 12.0 & \\
\hline Aves & Thraupidae & Dacnis lineata & 11.5 & \\
\hline Aves & Thraupidae & Dacnis cayana & 13.0 & \\
\hline Aves & Thraupidae & Cyanerpes caeruleus & 9.3 & \\
\hline Aves & Thraupidae & Cyanerpes cyaneus & 11.7 & \\
\hline Aves & Thraupidae & Chlorophanes spiza & 13.5 & \\
\hline Aves & Cardinalidae & Saltator grossus & 19.0 & $x$ \\
\hline Aves & Cardinalidae & Saltator maximus & 19.5 & \\
\hline Aves & Cardinalidae & Cyanocompsa cyanoides & 19.0 & \\
\hline Aves & Icteridae & Psarocolius viridis & 43.5 & \\
\hline Aves & Icteridae & Psarocolius decumanus & 39.5 & \\
\hline Aves & Icteridae & Cacicus cela & 25.5 & \\
\hline Aves & Icteridae & Cacicus haemorrhous & 24.5 & \\
\hline Aves & Icteridae & Cacicus chrysopterus & 20.5 & \\
\hline Aves & Fringillidae & Euphonia violacea & 9.5 & \\
\hline Aves & Thamnophilidae & Cymbilaimus lineatus & 18.0 & $x$ \\
\hline
\end{tabular}

Table S2. Tree species that were visited by frugivore mammals and birds in the Amapá National Forest (Amapá, Brazil), their average fruit characteristics, and sample size (i.e. number of measured fruits). $N=$ number of seeds.

\begin{tabular}{|c|c|c|c|c|c|c|c|c|}
\hline Tree species & Botanical family & $\begin{array}{l}\text { Visiting frugivore } \\
\text { species }\end{array}$ & $\begin{array}{l}\text { Fruit width } \\
(\mathrm{cm})\end{array}$ & $\begin{array}{l}\text { Fruit length } \\
\qquad(\mathrm{cm})\end{array}$ & $\begin{array}{l}N \text { seeds } \\
\text { per fruit }\end{array}$ & $\begin{array}{l}\text { Seed width } \\
\quad(\mathrm{cm})\end{array}$ & $\begin{array}{l}\text { Seed length } \\
(\mathrm{cm})\end{array}$ & $\begin{array}{l}\text { Sample } \\
\text { size }\end{array}$ \\
\hline Guatteria sp. & Annonaceae & $\begin{array}{l}\text { Brotogeris chrysoptera } \\
\text { Lipaugus vociferans }\end{array}$ & 1.20 & 1.85 & 1.0 & 1.00 & 1.70 & 3 \\
\hline $\begin{array}{l}\text { Protium nitidifolium (Cuatrec.) } \\
\text { Daly }\end{array}$ & Burseraceae & Bird not identified & 2.13 & 2.86 & 1.0 & 1.05 & 1.50 & 3 \\
\hline $\begin{array}{c}\text { Protium polybotrium (Turcz.) } \\
\text { Engl. }\end{array}$ & Burseraceae & Turdus fumigatus & 1.30 & 1.95 & 10.0 & 0.01 & 0.01 & 4 \\
\hline Buchenavia grandis Ducke & Combretaceae & Touit purpuratus & 1.85 & 3.21 & 1.0 & 1.01 & 2.23 & 4 \\
\hline Hirtella bicornis Mart. \& Zucc. & Chrysobalanaceae & $\begin{array}{l}\text { Lanio fulvus } \\
\text { Bird not identified }\end{array}$ & 0.29 & 1.00 & 1.0 & 0.50 & 0.70 & 1 \\
\hline Goupia glabra Aubl. & Goupiaceae & Trogon melanurus & 0.85 & 0.95 & 1.0 & 0.45 & 0.60 & 2 \\
\hline $\begin{array}{c}\text { Roucheria punctata (Ducke) } \\
\text { Ducke }\end{array}$ & Linaceae & Brotogeris chrysoptera & 1.81 & 2.40 & 1.0 & 0.52 & 0.79 & 14 \\
\hline $\begin{array}{c}\text { Miconia cuspidata Mart. ex } \\
\text { Naudin }\end{array}$ & Melastomataceae & $\begin{array}{l}\text { Bird not identified } \\
\text { Ramphocelus carbo } \\
\text { Pteroglossus viridis }\end{array}$ & 1.20 & 1.10 & $>100$ & 0.01 & 0.01 & 1 \\
\hline $\begin{array}{c}\text { Miconia tomentosa (Rico.) D. } \\
\text { Don ex DC. }\end{array}$ & Melastomataceae & $\begin{array}{l}\text { Pteroglossus viridis } \\
\text { Mionectes sp. } \\
\text { Selenidera piperivora } \\
\text { Myiarchus sp. } \\
\text { Saguinus midas }\end{array}$ & 1.15 & 1.65 & $>100$ & 0.01 & 0.01 & 2 \\
\hline $\begin{array}{c}\text { Virola bicuhyba (Schott ex } \\
\text { Spreng.) Warb. }\end{array}$ & Myristicaceae & $\begin{array}{l}\text { Turdus fumigatus } \\
\text { Ramphastos vitellinus }\end{array}$ & 1.40 & 2.40 & 1.0 & 0.80 & 1.20 & 2 \\
\hline Virola michelii Heckel & Myristicaceae & $\begin{array}{l}\text { Ramphastos vitellinus } \\
\text { Trogon melanurus } \\
\text { Turdus albicollis } \\
\text { Ateles paniscus }\end{array}$ & 0.90 & 1.27 & 1.0 & 0.50 & 0.69 & 4 \\
\hline
\end{tabular}


Table S2. Continued

\begin{tabular}{|c|c|c|c|c|c|c|c|c|}
\hline Tree species & Botanical family & $\begin{array}{l}\text { Visiting frugivore } \\
\text { species }\end{array}$ & $\begin{array}{l}\text { Fruit width } \\
\quad(\mathrm{cm})\end{array}$ & $\begin{array}{l}\text { Fruit length } \\
\qquad(\mathrm{cm})\end{array}$ & $\begin{array}{l}N \text { seeds } \\
\text { per fruit }\end{array}$ & $\begin{array}{l}\text { Seed width } \\
\quad(\mathrm{cm})\end{array}$ & $\begin{array}{l}\text { Seed length } \\
(\mathrm{cm})\end{array}$ & $\begin{array}{l}\text { Sample } \\
\text { size }\end{array}$ \\
\hline Virola michelii Heckel & Myristicaceae & $\begin{array}{l}\text { Ramphastos vitellinus } \\
\text { Bird not identified }\end{array}$ & 1.23 & 1.70 & 1.0 & 0.76 & 1.27 & 3 \\
\hline Eugenia sp1 & Myrtaceae & $\begin{array}{l}\text { Bird not identified } \\
\text { Lanio fulvus } \\
\text { Saltator grossus }\end{array}$ & 0.70 & 0.70 & 2.5 & 0.15 & 0.25 & 2 \\
\hline Myrcia grandis McVaugh & Myrtaceae & $\begin{array}{c}\text { Turdus sp. } \\
\text { Cymbilaimus lineatus } \\
\text { Tachyphonus rufus }\end{array}$ & 1.00 & 1.10 & 1.0 & 0.86 & 0.80 & 3 \\
\hline Neea altissima Poepp. \& Endl. & Nyctaginaceae & Mionectes sp. & 0.43 & 0.54 & 1.0 & 0.19 & 0.39 & 4 \\
\hline $\begin{array}{l}\text { Manilkara huberi (Ducke) } \\
\text { Standl. }\end{array}$ & Sapotaceae & Ramphastos vitellinus & 1.79 & 1.73 & 1.0 & 0.65 & 1.20 & 8 \\
\hline Micropholis trunciflora Ducke & Sapotaceae & Turdus fumigatus & 2.09 & 2.52 & 1.0 & 0.92 & 1.45 & 2 \\
\hline Pouteria pallens TD Penn. & Sapotaceae & Touit purpuratus & 3.03 & 3.12 & 1.0 & 2.40 & 2.88 & 5 \\
\hline $\begin{array}{c}\text { Pourouma tomentosa Mart. } \\
\text { ex Miq. }\end{array}$ & Urticaceae & Piculus flavicula & 1.06 & 1.57 & 1.0 & 0.85 & 1.15 & 3 \\
\hline $\begin{array}{l}\text { Pourouma tomentosa Mart. } \\
\text { ex Miq. }\end{array}$ & Urticaceae & Trogon melanurus & 1.23 & 1.70 & 1.0 & 0.82 & 1.10 & 2 \\
\hline
\end{tabular}

Table S3. Dependent and independent variables included, the correspondent error distribution, and sampling units of the full models to perform the multi-model inference analyses to investigate niche segregation mechanisms among diurnal canopy frugivores and zoochoric trees in the Amapá National Forest (Amapá, Brazil).

\begin{tabular}{|c|c|c|c|}
\hline Dependent variable & Independent variables & Sampling unit & Error distribution \\
\hline Frugivore size & $\begin{array}{c}\text { Fruit weight + Fruit size }+ \text { Fruit's smallest dimension + Seed size + } \\
\text { Seed smallest dimension + Tree DBH }\end{array}$ & $\begin{array}{c}\text { Each individual/group of frugivore that } \\
\text { visited the trees }\end{array}$ & Gaussian \\
\hline Seed swallowed or not & $\begin{array}{l}\text { Fruit weight + Fruit size + Fruit smallest dimension + Seed size + } \\
\text { Seed smallest dimension + Frugivore size }\end{array}$ & $\begin{array}{l}\text { Each individual/group of frugivore that } \\
\text { visited the trees }\end{array}$ & Binomial \\
\hline Frugivore richness & $\begin{array}{l}\text { Fruit weight + Fruit size + Fruit smallest dimension }+ \text { Seed size }+ \\
\text { Seed smallest dimension }+ \text { Tree DBH + Prevalence of ripe fruit in the } \\
\text { month }\end{array}$ & Each visited tree & Poisson \\
\hline Frugivore abundance & $\begin{array}{c}\text { Fruit weight }+ \text { Fruit size + Fruit smallest dimension + Seed size + } \\
\text { Seed smallest dimension + Tree DBH + Prevalence of ripe fruit in the } \\
\text { month }\end{array}$ & Each visited tree & Poisson \\
\hline
\end{tabular}

Table S4. List of the 72 focal trees monitored in the Amapá National Forest (Amapá, Brazil), with the number of frugivore individuals and species recorded feeding on their fruits. $N=$ number of individuals/species.

\begin{tabular}{lccc}
\hline Focal tree species & $\begin{array}{c}\text { N frugivore } \\
\text { individuals }\end{array}$ & $\begin{array}{c}\text { N frugivore } \\
\text { species }\end{array}$ & $\begin{array}{c}\text { Month of } \\
\text { monitoring }\end{array}$ \\
\hline Buchenavia congesta & - & - & June \\
\hline Buchenavia grandis & 2 & 1 & May \\
\hline Buchenavia grandis & - & - & May \\
\hline Duroia macrophylla & - & - & February \\
\hline Duroia macrophylla & - & - & February \\
Duroia macrophylla & - & - & February \\
\hline Eugenia cupulata & - & - & September \\
\hline Eugenia cupulata & - & - & September \\
\hline Eugenia sp. & 4 & 3 & September \\
Goupia glabra & 1 & 1 & March \\
\hline
\end{tabular}

Table S4. Continued.

\begin{tabular}{lccc}
\hline Focal tree species & $\begin{array}{c}\text { N frugivore } \\
\text { individuals }\end{array}$ & $\begin{array}{c}\text { N frugivore } \\
\text { species }\end{array}$ & $\begin{array}{c}\text { Month of } \\
\text { monitoring }\end{array}$ \\
\hline Goupia glabra & - & - & July \\
Goupia glabra & - & - & June \\
Guatteria citriodora & - & - & August \\
Guatteria hypoglauca & - & - & April \\
Guatteria olivacea & - & - & March \\
Guatteria sp. & 2 & 2 & April \\
Hirtella bicornis & 3 & 2 & August \\
Hirtella bicornis & - & - & August \\
Hirtella rodriguesii & - & - & August \\
Licania bracteata & - & - & April \\
Licania bracteata & - & - & April \\
\hline
\end{tabular}


Table S4. Continued.

\begin{tabular}{lccc}
\hline Focal tree species & $\begin{array}{c}\text { N frugivore } \\
\text { individuals }\end{array}$ & $\begin{array}{c}\text { N frugivore } \\
\text { species }\end{array}$ & $\begin{array}{c}\text { Month of } \\
\text { monitoring }\end{array}$ \\
\hline Licania octandra & - & - & May \\
\hline Manilkara bidentata & - & - & May \\
\hline Manilkara huberi & - & - & January \\
\hline Manilkara huberi & 3 & 1 & February \\
\hline Manilkara huberi & - & - & March \\
\hline Manilkara huberi & - & - & March \\
\hline Manilkara huberi & - & - & June \\
\hline Miconia cuspidata & 5 & 3 & July \\
Miconia pyrifolia & - & - & July \\
\hline Miconia tomentosa & 13 & 5 & July \\
Micropholis guyanensis & - & - & June \\
\hline Micropholis guyanensis & - & - & July \\
\hline Micropholis guyanensis & - & - & August \\
\hline Micropholis trunciflora & 1 & 1 & August \\
\hline Myrcia floribunda & - & - & February \\
\hline Myrcia grandis & - & - & August \\
\hline Myrcia grandis & - & - & September \\
\hline Neea altissima & - & - & February \\
\hline Neea floribunda & - & - & January \\
\hline Neea madeirana & - & February \\
\hline Ocotea negrensis & - & - & February \\
\hline Ocotea percurrens & - & September \\
\hline Ocotea percurrens & - & - & June \\
\hline Pouberula & - & - & September \\
\hline
\end{tabular}

Table S4. Continued.

\begin{tabular}{|c|c|c|c|}
\hline Focal tree species & $\begin{array}{l}\text { N frugivore } \\
\text { individuals }\end{array}$ & $\begin{array}{l}\text { N frugivore } \\
\text { species }\end{array}$ & $\begin{array}{l}\text { Month of } \\
\text { monitoring }\end{array}$ \\
\hline Pourouma tomentosa & - & - & September \\
\hline Pouteria engleri & - & - & August \\
\hline Pouteria pallens & 2 & 1 & June \\
\hline Pouteria peruviensis & - & - & January \\
\hline Pouteria peruviensis & - & - & June \\
\hline Protium nitidifolium & 2 & 1 & July \\
\hline Protium polybotrium & 2 & 1 & June \\
\hline Protium trifoliatum & - & - & June \\
\hline Roucheria punctata & - & - & March \\
\hline Roucheria punctata & 2 & 1 & April \\
\hline Roucheria punctata & - & - & April \\
\hline Sextonia rubra & - & - & July \\
\hline Sextonia rubra & - & - & July \\
\hline Sextonia rubra & - & - & July \\
\hline Siparuna decipiens & - & - & March \\
\hline Siparuna decipiens & - & - & May \\
\hline Siparuna monogyna & - & - & September \\
\hline Siparuna sp. & - & - & March \\
\hline Theobrama subincanum & - & - & March \\
\hline Theobrama subincanum & - & - & April \\
\hline Theobrama subincanum & - & - & April \\
\hline Theobrama subincanum & - & - & June \\
\hline Virola bicuhyba & 3 & 2 & September \\
\hline Virola michelli & 17 & 4 & January \\
\hline Virola michelli & 3 & 2 & August \\
\hline
\end{tabular}

Table S5. Model-averaging results based on Akaike weights of the models with $\triangle \mathrm{AICC}$ (difference between the AICC of a given model and the AICc of the most parsimonious model) $\leq 2.0$. None of the dependent variables was considered important for predicting frugivore richness on fruit-bearing trees in the Amapá National Forest (Amapá, Brazil), since they presented importance values $<0.4$. Coefficients, standard errors, and $P$-values were conditionally averaged. DBH $=$ tree diameter at breast height.

\begin{tabular}{lccc}
\hline Independent variables & Coefficient \pm SE & $p$ & Variable Importance \\
\hline Seed's longest dimension & $0.334 \pm 0.190$ & 0.100 & 0.25 \\
Fruit size & $-0.327 \pm 0.208$ & 0.142 & 0.20 \\
Fruit's longest dimension & $0.262 \pm 0.178$ & 0.171 & 0.15 \\
Seed size & $-0.311 \pm 0.261$ & 0.265 & 0.12 \\
DBH & $-0.235 \pm 0.177$ & 0.217 & 0.12 \\
\hline
\end{tabular}


ACTA

AMAZONICA

TODESCHINI et al. Niche differentiation among frugivores and zoochoric trees

Table S6. Models used in model averaging, their AlCc and Akaike weights (see model averaging results in Table 2).

\begin{tabular}{|c|c|c|c|}
\hline $\begin{array}{l}\text { Dependent } \\
\text { variable }\end{array}$ & Independent variables & $\mathrm{AICC}$ & $\begin{array}{l}\text { Akaike } \\
\text { weight }\end{array}$ \\
\hline \multirow[t]{2}{*}{ Frugivore size } & Fruit weight + Seed size & 102.71 & 0.62 \\
\hline & $\begin{array}{c}\text { Fruit weight }+ \text { Seed size }+ \text { Tree } \\
\text { DBH }\end{array}$ & 103.68 & 0.38 \\
\hline \multirow[t]{6}{*}{$\begin{array}{l}\text { Seed swallowed } \\
\text { or not }\end{array}$} & $\begin{array}{l}\text { Frugivore size }+ \text { Fruit weight }+ \\
\text { Fruit smallest dimension }\end{array}$ & 41.34 & 0.26 \\
\hline & $\begin{array}{l}\text { Frugivore size }+ \text { Fruit weight }+ \\
\text { Fruit smallest dimension }+ \text { Seed } \\
\text { size }\end{array}$ & 41.86 & 0.20 \\
\hline & $\begin{array}{l}\text { Frugivore size + Fruit weight }+ \\
\text { Fruit smallest dimension }+ \text { Seed } \\
\text { smallest dimension }\end{array}$ & 41.91 & 0.20 \\
\hline & $\begin{array}{l}\text { Frugivore size }+ \text { Fruit weight }+ \\
\text { Fruit size }\end{array}$ & 42.78 & 0.13 \\
\hline & $\begin{array}{c}\text { Frugivore size + Fruit weight } \\
+ \text { Fruit size }+ \text { Seed smallest } \\
\text { dimension }\end{array}$ & 43.08 & 0.11 \\
\hline & $\begin{array}{c}\text { Frugivore size + Seed smallest } \\
\text { dimension + Fruit smallest } \\
\text { dimension }\end{array}$ & 43.20 & 0.10 \\
\hline \multirow[t]{4}{*}{$\begin{array}{l}\text { Frugivore } \\
\text { abundance }\end{array}$} & Seed smallest dimension & 115.28 & 0.43 \\
\hline & $\begin{array}{l}\text { Seed smallest dimension }+ \\
\text { Prevalence of ripe fruit in the } \\
\text { month }\end{array}$ & 116.44 & 0.24 \\
\hline & $\begin{array}{l}\text { Seed smallest dimension + Fruit } \\
\text { size }\end{array}$ & 117.14 & 0.17 \\
\hline & $\begin{array}{c}\text { Seed smallest dimension + Tree } \\
\text { DBH }\end{array}$ & 117.27 & 0.16 \\
\hline
\end{tabular}

